\title{
「マルチーペタワットレーザーの最前線」特集号によせて
}

\author{
加藤 義章 \\ 光産業創成大学院大学 ( ₹431-1202 静岡県浜松市西区呉松町1955-1)
}

\section{Preface to Special Issue on Frontier of Multi-Petawatt Lasers}

\author{
Yoshiaki KATO \\ The Graduate School for the Creation of New Photonics Industries, 1955-1 Kurematsu, Nishi-ku, Hamamatsu, Shizuoka 431-1202
}

(Received November 30, 2017)

マルチーペタワット $(\mathrm{PW})$ レーザーの開発が世界的に進 められている。本特集では日米欧仏中におけるPW級 レーザーが紹介される. 超高出力レーザーは通常, チ夕 ンサファイア(Ti:sapphire) 結晶を増幅媒質とするチャー プパルス増幅 (Chirped Pulse Amplification: CPA) システム であるが，より極短パルス化が可能な光パラメトリック 増幅 (Optical Parametric Chirped Pulse Amplification: OPCPA) システム開発も実施されている.

超高出力レーザーを生成し利用するには，スペクト ル・時間・空間域において, レーザー光の振幅と位相を 高度に制御することが必要である。量子科学技術研究機 構で，高度に制御されたTi:sapphire PWレーザーJ-KAREN-Pが稼働を開始した。また，韓国IBS CoReLS（Institute for Basic Science Center for Relativistic Laser Science) で4 PWレーザーが稼働開始し，10 PWシステム建設が欧 州ELI (Extreme Light Infrastructure), 仏LULI(Laboratoire d'Utilisation des Lasers Indeses) で進められている。一方中 国上海光学研究所 (Shanghai Institute of Optics and Fine Mechanics: SIOM) のOPCPAシステムを基に, $100 \mathrm{PW}$ OPCPAレーザー・硬X線レーザー複合システム建設 （上海浦東地区）が2017年に予算化され， G. Mourou, T. Tajimaらが提唱してきた非線形量子電磁気学の実験が現 実的になってきた。

ここに至る歴史を少し振り返ってみよう。高出力レー ザーの先鞭は，D. Strickland, G. MourouのCPA提案(1985) でつけられた. CPA Ti:sapphireの高出力化がUCSD (University of California, San Diego) (米), LOA (Le Laboratoire d'Optique Appliquée) (仏) 等で進められ, 100 TW, $19 \mathrm{fs}, 10 \mathrm{~Hz}$ システムが, 日本原子力研究所光量子科学 研究センター (Advanced Photon Research Center: APRC) で1998年に初めて実現された。同センターの新施設がけ
いはんな学研都市木津地区に2000年に竣工し, 極短パル ス超高強度レーザーを用いた光量子科学研究が本格的に 開始された。

2001年5月に新施設紹介を兼ね，APRCでOECD Global Science Forum Workshop on Compact High-Intensity ShortPulse Lasers: Future Directions and Applications が開催され た。 日米欧露韓等から約60名が参加して詳細な議論が交 わされ，極短・高強度レーザーが，学術・産業・医療等 広範囲の分野に大きなインパクトをもたらすとの認識が 共有されることとなった。

これを基に, IUPAPにICUIL (International Committee on Ultrahigh Intensity Lasers) が2004年に設置され，超高 出力レーザー及び高強度光科学の推進について検討する 場が確立された。

欧州では，2002年に開始されたESFRI（European Strategy Forum on Research Infrastructures）Roadmap提案へ向 けて，欧州レーザー施設を共用するLASERLAB EUROPE がW.Sandner(独)により推進された。これを基盤とし， G. Mourouを代表とするELI構想が採択され，2009年にチエ コ, ハンガリー, ルーマニアのELI施設が決定され, 夫々 ELI-Beamlines, ELI-NP (nuclear physics), ELI-ALPS建設 が進められており，2018年に稼働が開始される.

近年, 高強度レーザーによる実用化技術実現への関心 が高まり，レーザーを用いた加工，放射線源（X線，ガン マ線, 中性子線), 粒子加速器, 医療等の応用プロジェク トが開始されている。これらの応用において，現在のレー ザーシステムは, 効率・繰り返し・出力・安定性等の面で 十分とは言えず，新たなコンセプトに基づくシステムの開 発が必要な段階に至っている。わが国で実施されている 高強度レーザーに関する高度な研究・技術基盤をフルに 活かし，世界最先端のレーザー・応用技術を実現したい。 